\title{
Argümantasyon Tabanlı Bilim Eğitiminde Etkileşimsel Kaynaklar ve Öğretmen Soruları ${ }^{*}$ Metin ŞARDAG ${ }^{* *}$ ve Gültekin ÇAKMAKCI***
}

Öz: Sınıf içi etkileşim, öğrenme sürecinin dinamiklerini şekillendirmekte olup anlamlı öğrenmeler için zemin oluşturabilmektedir. Bu çalışmada sınıf içi etkileşime odaklanılarak argümantasyon tabanlı bilim eğitiminde fen bilimleri öğretmenleri tarafında kullanılan etkileşimsel kaynaklar, etkileşimsel kaynak olarak kullanılan sorular ve bu soruların kullanım amaçları araştırılmıştır. Bu bağlamda çalışma Konuşma Çözümlemesi bakış açısıyla nitel bir araştırma olarak yürütülmüştür. Çalışma biri kadın, ikisi erkek olmak üzere üç Fen Bilimleri öğretmeniyle 2016-2017 eğitim öğretim yılında 7. sınıf öğrencileriyle Elektrik Enerjisi ünitesinde yürütülmüsştür. Toplamda 49 saatlik (ders saati) sınıf içi etkileşim verisi toplanmıştır. Toplanan veriler Gail Jefferson transkript sistematiğine göre transkript edilmiştir. Toplanan veriye gerekçesiz arama ve içerden bakış açısıyla yaklaşılmıştır. Sonuçlar öğretmenlerin diyalojik argümantasyonu desteklemek için bazı etkileşimsel kaynaklar kullandıklarını göstermiştir. Ayrıca öğretmenler etkileşimsel kaynak olarak yankı soruları (netleştirme istemi, anlamayı kontrol etme ve teyit etme soruları) ve epistemik soruları (gösterim ve gönderimsel sorular) kullanmışlardır. Öğretmenler bu soruları öğretimsel bağlama bağlı olarak farklı amaçlarda kullanmaktadırlar. Çalışma bulguları etkileşim kalitesinin artırılması açısından mevcut literatüre katkıda bulunmaktadır.

Anahtar kelimeler: Argümantasyon, Etkileşimsel kaynaklar, Konuşma çözümlemesi, Öğretmen sorular1

\footnotetext{
* Bu çalışma, birinci yazarın "Argümantasyon Tabanlı Bilim Eğitiminde Biçimlendirici Değerlendirme: Bir Konuşma Çözümlemesi Araştırması" isimli doktora tezinden üretilmiştir. Ayrıca 30 Ağustos-3 Eylül 2021 tarihlerinde gerçekleştirilen “14th European Science Education Research Association (ESERA) Conference”da sözlü bildiri olarak sunulmuştur.

** Arş. Gör. Dr., Van Yüzüncü Y1l Üniversitesi, Matematik ve Fen Bilimleri Eğitimi Bölümü, Orcid No: 0000-00032162-8289, Email: metinsardag@yyu.edu.tr

**** Prof. Dr., Hacettepe Üniversitesi, Matematik ve Fen Bilimleri Eğitimi Bölümü, Orcid No: 0000-0003-2003-2520, Email: cakmakci@hacettepe.edu.tr
} 


\title{
Interactional Resources and Teacher's Questions in Argumentation-Based Science Education
}

\begin{abstract}
Classroom interaction shapes the dynamics of the learning process and might provide the basis for meaningful learning. This study investigates the interactional resources used by science teachers, the questions used as interactional resources, and the purposes of these questions in argumentation-based science education by focusing on classroom interaction. Drawing upon that, this study was set as a qualitative nature in the perspective of Conversation Analysis. One female and two male teachers enrolled in the study. The teachers performed classroom implementations with their 7th-grade students in the Electrical Energy unit in the 2016-2017 academic year. Forty-nine lesson hours of data were collected. The collected classroom interaction data was transcribed regarding the principles of Gail Jefferson transcript system. Data were approached by the emic perspective and unmotivated search. The results show that the teachers use some interactional resources in their lessons to support dialogical argumentation. In addition, the teachers use echoic questions - clarification request questions, comprehension check questions, and confirmation check questions - and epistemic questions - display questions and referential questions as interactional resources. The teachers use these questions for different purposes depending on the instructional contexts. The findings offer implications to improve the quality of interaction in education.
\end{abstract}

Keywords: Argumentation, Conversation analysis, Interactional resources, Teacher's questions

\section{Giriş}

Argümantasyon, bilimin temel bileşeni olmakla birlikte fen eğitiminde yaygın bir şekilde kullanılan analitik bir çerçevedir (Erduran, 2019). Fen bilimleri eğitimiyle ilgili pek çok politika dokümanında ve öğretim programında öğrenme süreci için özellikle üzerinde durulmaktadır. Örneğin National Research Council [NRC] (2012) açık bir şekilde fen ve mühendislik programı içerisine "delillerle argümanı ilişkilendirme" unsurunu yerleştirerek argümantasyonu desteklemektedir. Benzer bir biçimde 2018 Fen Bilimleri Dersi Öğretim Programı (Milli Eğitim Bakanlığı [MEB], 2018) içeriğinde benimsenen yöntem ve stratejilerde argüman oluşturma, 
iddiaları çürütmeye yönelik karşıt argümanlar geliştirme açık bir şekilde belirtilmiştir. Fen eğitiminde argümantasyonun bu şekilde açık ve net olarak desteklenmesinde bireylerin gelişimine yönelik sunabileceği potansiyel katkılar önemli yer tutmaktadır. Argümantasyon bilim konuşma, iletişim becerilerini geliştirme, mantıksal akıl yürütme, eleştirel düşünme, bilimsel kültür içinde kültürlenme, bilimi toplumsallaştırma ve bilişsel süreçleri görünür yapmaya katkı sağlamaktadır (Erduran \& Jiménez-Aleixandre, 2007). Pek çok araştırmacı, yürüttüğü araştırmalarla da bu hususları desteklemektedir (Chin \& Osborne, 2010; Duschl, 2007). Bahsedilen katkıların özellikle bilim konuşmanın sınıfta meydana gelebilmesi için argümantasyon sürecinin, özellikle diyalojik argümantasyon sürecinin başarılı bir şekilde yürütülmesi gerekmektedir. Diyalojik argümantasyon süreci, öğretmenlerin ve öğrencilerin iddiaları ve delilleri eleştirel bir şekilde inceleme ve sunma konusunda işbirliği yaptığı, dilin aracı olduğu bir süreçtir ve tüm katılımcıların fikirleri sorgulama, değerlendirme (Lehesvuori vd., 2017) ve onlara meydan okuma firsatına sahip olmasını gerektirir (Berland \& McNeill, 2010). Fakat diyalojik argümantasyon sürecinde, sürecin doğrusal olmayan yapısı nedeniyle öğrenciler ve öğretmenler çeşitli zorluklarla karşılaşmaktadır (Kim \& Roth, 2018). Ayrıca öğretmenlerin sınıf içerisinde argümantasyon faaliyetleri yürütmeleri için firsat sağlayan öğretim programı kullanıyor olsa dahi diyalojik argümantasyon için gereken ortamı oluşturma ve kullanmada (Alozie, Moje, \& Krajcik, 2010) ve süreç içerisinde öğrenci öğrenmelerini desteklemek için uygun soruları üretme ve kullanmada problem yaşadıkları (McNeill \& Knight, 2013) bilinmektedir. Bu sebeplerden dolayı bu araştırmada sınıf içi etkileşime odaklanarak argümantasyon tabanlı bilim eğitiminde, fen bilimleri öğretmenleri tarafından kullanılan etkileşimsel kaynaklar, etkileşimsel kaynak olarak kullanılan sorular ve bu soruların kullanım amaçlarının araştırılması amaçlanmaktadır.

\section{Sınıf İçi Etkileşimde Etkileşimsel Kaynaklar ve Sorular}

Etkileşimsel kaynaklar, etkileşimde anlamı inşa etmek için katılımcıların kullandıkları ifadelerin özellikleri olarak ele alınmakta (Mondada, 2007) ve etkileşim sırasında daha sonraki etkileşim sözcelerinin tasarımı için kullanılabilmektedir (Jefferson, 1974). Bu bağlamda sınıf içi etkileşimin bir unsuru olan öğretmen tarafından üretilen ifadeler ve bunların özellikleri, özellikle de sorular sınıf içi etkileşimde anlam oluşturmak için önemli unsurlardır. Nitekim öğretmen tarafindan derste öğrencilere yöneltilen sorular, sınıf içi etkileşimin yaygın bir bileşeni olup (Eshach, Dor-Ziderman, \& Yefroimsky, 2014; Furtak, Bakeman, \& Buell, 2018; Halvorsen, 2018) 
hem fen eğitimi gerçekleştirilirken kullanılan söylemin doğasını belirlemede (Chin, 2007; Kääntä \& Kasper, 2018) hem de öğrenci düşüncelerini harekete geçirme, şekillendirme ve ortaya çıkarmada belirgin bir potansiyele sahiptir (Kawalkar \& Vijapurkar, 2013). Çünkü öğretmen tarafından kullanılan soru türleri ve kullanılma yolları öğrencilerin dahil olacakları bilişsel süreci etkilemektedir (Chin, 2007). Ayrıca öğrencilerin dikkatini öğretim süreci içerisinde çeşitli hususlara çekme, öğretimsel amaçlar bağlamında sürece dahil etme ve amaçları gerçekleştirmede (Erdogan \& Campbell, 2008), öğrencilerin mantıksal akıl yürütme, düşünme ve argümantasyon için uygun sınıf ortamının oluşturulmasına katkı sağlamaktadır (Kawalkar \& Vijapurkar, 2013).

Özellikle dilbilim alanında sıklıkla kullanılan konuşma çözümlemesi yaklaşımıyla gerçekleştirilen araştırmalarda sınıf konuşmalarında nelerin meydana geldiğine ve nasıl gerçekleştiğine yönelik odaklanılırken oldukça az sayıda çalışmanın sınıf içi etkileşimde sorular üzerine odaklandığı görülmektedir (Waring, 2012b). Bu hem dilbilim hem de fen eğitimi alanı için bir eksiklik olarak görülebilir. Çünkü sorular hem doğal olarak gerçekleşen konuşmada söylemsel etkileşimin önemli bir unsuru hem de görüşleri sorgulama ve etkileşimi sürdürme imkanı sunduğundan (Chin \& Osborne, 2010) sınıf içi etkileşimde ön plana çıkmaktadır. Ayrıca öğretmen tarafından üretilen sorular, öğrencilerin anlamlarını netleştirme, farklı bakış açılarının farkına varmalarına katkı sağlamaktadır (van Zee, Iwasyk, Kurose, Simpson, \& Wild, 2001).

Öğretmenin kullandığı soru türleri ve kullanma yollarının bilişsel süreçte farklı etkilere sahip olduğu (Chin, 2007) bilinmektedir. Koshik (2002) tarafından yürütülen bir araştırmada da ikinci dilde yazma üzerine odaklanılan toplantılarda öğretmen tarafından üretilen evet/hayır sorularının, üzerinde durulan hususa yönelik karşıt iddialar iletmek, özellikle öğrencilerin ürettikleri yazılardaki problemli hususları göstermek amacıyla kullandığı ortaya konulmaktadır. Nitekim kişi tarafından üretilen evet/hayır yanıtlı soruların ve cevaplarının bilgi dağıtımını yönetmek için kullanıldığı (Raymond, 2003) ve kimi zaman da etkileşime konu olan iddiaların teyit edilmesi için kullanıldığı belirtilmektedir (Bennett, 1982). Dolayısıyla bu tür evet/hayır sorularının etkileşim içerisinde eleştirel bir durum ortaya koyma eğiliminde olması üzerine odaklanıldığında, öğrencilerin fikirleri ele alma, düşünmelerine yönelik tam olarak eşit imkânlar ve alternatifler sağlamamasından kaynaklı olarak verimli düşünme aracı olarak ele alınmamaktadırlar (Waring, 2012b). Öte yandan problem çözme sürecine rehberlik, öğrenci hazır bulunuşluluğunu değerlendirme ve yeteneğini tanıma, tartışma ortamı oluşturma, eleştirel 
düşünme ve yaratıcılığı teşvik etme amaçları da bulunmaktadır. Nitekim bu amaçların gerçekleştirilebilmesi için farklı soru türlerine ihtiyaç olduğu da aşikardır (Cunningham, 1987). Alanyazında bu tarz soru türleri farklı araştırmacılar tarafından çeşitli şekillerde ele alınmaktadır. $\mathrm{Bu}$ araştırmada Long ve Sato (1983) tarafından ortaya konulmuş olan yankı sorular (echoic questions) ve epistemik sorular (epistemic questions) sınıflaması kullanılmaktadır. Yank1 sorular sınıf içi etkileşimde tartışmayı başlatmak, süreçte ele alınacak konuyu tanıtmak ya da kavramlar, olaylar, durumlara yönelik öğrenci anlamalarını açı̆̆a çıkarmak amacıyla tercih edilmektedir (Oliveira, 2010). Bu doğrultuda yank1 sorular; 1) öğrenenlerin iletilen bilgiyi anlayıp anlamadıklarını ortaya çıkarmak amacıyla kullanılan anlamanın kontrolü soruları (comprehension check questions), 2) etkileşime konu olan hususu netleştirmek için üretilen netleştirme istemi soruları (clarification request questions) ve 3) öğrenenler tarafından iletilen bilginin öğretmen tarafından doğru anlaşılıp anlaşılmadığını ortaya koymak amacıyla teyit sorularını (confirmation check questions) içermektedir. Netleştirme istemleri ve teyit etmeler üretilen yanıtların farklı şekilde ifade edilmesi veya açıklanmasına yönelik öğrenen katkısını yeniden organize etmeye teşvik ettiği için öğrenmeyi desteklemede önemli unsurlar olarak düşünülmektedir (Suryati, 2015; Walsh, 2006). Epistemik sorular ise gösterim soruları (display questions), gönderimsel soruları (referential questions), anlatımsal soruları (expressive questions) ve retorik soruları (rhetorical questions) bünyesinde barındırmaktadır (Long \& Sato, 1983). Bu çalışmada gösterim ve gönderimsel sorular ele alınmaktadır. Gösterim soruları alan yazında yanıtı bilinen, gönderimsel sorular ise yanıtı bilinmeyen sorular olarak ele alınmaktadır (Long \& Sato, 1983; Mehan, 1979). Bu sorular sınıf içi etkileşimde öğrenci tarafından üretilen yanıtları ortaya çıkarma, ortaya konulan katkıları, süregelen tartışmaları devam ettirmeye yönelik kullanılmaktadır. Dolayısıyla bu soruların ön plana çıkan özelliği de kendinden önce gelen sözcelerdeki bilgi unsurlarını yansıtması ve devam ettirmesidir (Oliveira, 2010).

\section{Çalışmanın Önemi}

Fen eğitiminde argümantasyon alanında yapılan çalışmalar incelendiğinde ağırlıklı olarak öğrenen tarafindan yazılı olarak üretilen argümanın niteliği ve bunun değerlendirilmesi üzerine odaklanıldığı görülmektedir (Aydeniz \& Gurcay, 2013; Erduran, Simon, \& Osborne, 2004; Osborne, Erduran, \& Simon, 2004a; Sampson, Grooms, \& Walker, 2011). Yazılı argümana nazaran daha az sayıda çalışmada ise diyalojik argümantasyon faaliyetlerinin incelendiği ve 
bunlara yönelik analitik çerçeveler oluşturulmaya veya bakış açıları sunmaya çalışıldığı aşikardır (Clark, Sampson, Weinberger, \& Erkens, 2007; Kim \& Roth, 2018; Nussbaum, 2011). Bu çalışmalarda karşıt argümanlar karşı karşıya geldiğinde her ne kadar meydana gelmesi olası senaryolar belirlenmiş (Leitão, 2000) olsa da sınıf içi etkileşimde argümantasyon faaliyetlerinin etkileşimsel olarak nasıl desteklendiği ve bu sırada soruların nasıl kullanıldığına yönelik bütünleşik olarak alana ışık tutan çalışmalara ihtiyaç olduğu düşünülmektedir. Çünkü bu tür çalışmalar aracılığıyla argümantasyon sürecindeki sınıf içi etkileşim unsurları ortaya konulabilir ve öğrenmelerin desteklenmesi için zemin oluşturulabilir. Bu çalışmanın bahsi geçen hususlara yönelik bilgi sağlayacağı düşünüldüğü için alana özgün katkı sağlayacağı öngörülmektedir. Ayrıca bu çalışmada yöntem olarak kullanılan Konuşma Çözümlemesinin fen eğitimi alanında nasıl kullanılabileceğine yönelik örnekler sunması nedeniyle fen eğitimi alanına farklı bakış açıları kazandıracağ düşünülmektedir.

Yukarıda bahsedilen unsurlar bağlamında bu çalışmada sınıf içi etkileşime odaklanarak argümantasyon tabanlı bilim eğitiminde, fen bilimleri öğretmenleri tarafindan kullanılan etkileşimsel kaynaklar, etkileşimsel kaynak olarak kullanılan sorular ve bu soruların kullanım amaçlarının araştırılması amaçlanmaktadır. Bu amaç kapsamında aşağıda yer verilen araştırma sorularına yanıt aranmıştır.

- Argümantasyon tabanlı bilim eğitiminde fen bilimleri öğretmenleri tarafindan kullanılan etkileşimsel kaynaklar nelerdir?

- Argümantasyon tabanlı bilim eğitiminde fen bilimleri öğretmenleri tarafından etkileşimsel kaynak olarak kullanılan sorular ve bu soruların kullanım amaçları nelerdir?

\section{Yöntem}

Bu çalışma Konuşma Çözümlemesi (KÇ) (Sidnell, 2010; Silverman, 2014) bakış açısıyla nitel bir araşıırma olarak yürütülmüşsür. KÇ bir sosyal etkileşim araştırma yaklaşımı olup çeşitli bağlam ve ortamlarda tekrarlanan konuşmaların ele alındığı bir yaklaşımdır (Sidnell, 2009). Ayrıca bireylerin konuşma ve sözlü iletişimlerinin bilimsel esaslar doğrultusunda ele alınmasına olanak tanımaktadır (Sert, Balaman, Can Daşkın, Büyükgüzel, \& Ergül, 2015).

\section{Araştırmanın Bağlamı}


$\mathrm{Bu}$ araştırma üç temel aşamada yürütülmüştür. Birinci aşamada gönüllü öğretmenlerin belirlenmesi ve öğretmen eğitiminin yürütülmesi yer almaktadır. İkinci aşama öğretmen eğitimine katılan öğretmenlerden gönüllü olanlar ile sınıf içi uygulamalarının yürütülmesidir. Son aşama ise süreçte elde edilen uygulama verilerinin konuşma çözümlemesi bakış açısıyla incelenmesidir. Araştırma sürecinde takip edilen basamaklar Şekil 1'de verilmiştir.

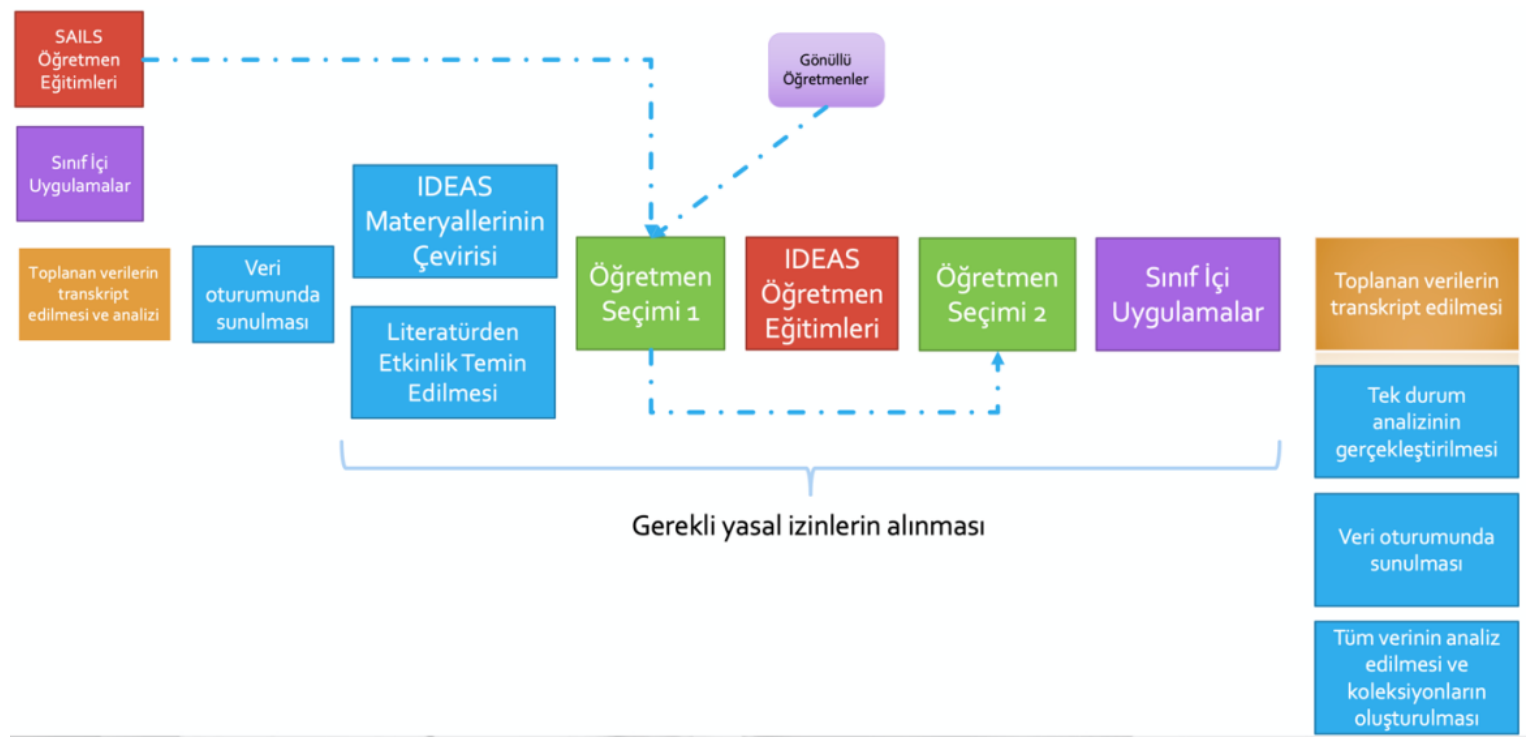

Şekil 1. Araştırma süreci

\section{Araştırmanın Çalışma Grubu ve Öğretmen Eğitimi}

Araştırmanın katılımcı öğretmenlerinin belirlenmesi iki aşamada gerçekleştirilmiştir. İlk olarak 2015 yılında Van ilinde yürütülmüş Araştırma-Sorgulama Temelli Bilim Eğitiminde Değerlendirme Stratejileri (SAILS) (sails-project.eu) isimli Avrupa Birliği projesi faaliyetlerine katılmış ve bu çalışma için gönüllü olan fen bilimleri öğretmenleri belirlenmiştir. Öğretmenler belirlenirken SAILS eğitimlerine katılmış olmalarının göz önünde bulundurulmasının temel nedeni öğretmenlerin değerlendirme stratejilerini deneyimlemeleri ve bu deneyimlerini sınıflarındaki argümantasyon eğitimlerine transfer edebilecekleri düşüncesidir. Ayrıca 2016-2017 eğitim öğretim yılında 7. sınıf öğrencileri ile derslerinin olmasına dikkat edilmiştir. Bu doğrultuda sekiz fen bilimleri öğretmeni araştırmaya katılmak için gönüllü olmuştur. İkinci aşamada argümantasyona yönelik öğretmen eğitimi gerçekleştirilmiş ve bu eğitim sonrasında katılımcı öğretmenlerin cinsiyetleri, eğitim-öğretim faaliyetlerini yürüttükleri öğrenci profilleri, her iki öğretmen eğitimlerinde süreçte sergilemiş oldukları performanslar ve ilgi durumları göz önünde 
bulundurularak farklı ortaokullarda görev yapan iki erkek bir kadın öğretmen seçilmiştir. Öğretmenler lisans mezunu olup erkek öğretmenlerden birinin 6 yıl, diğeri 5 yıl, kadın öğretmenin ise 5 yıllık mesleki deneyimi bulunmaktadır. Bahsedilen kriterler sınıf içi etkileşimi çeşitlendireceği ve zenginleştireceği düşüncesiyle göz önünde bulundurulmuştur. $\mathrm{Bu}$ öğretmenlerin eğitim verdikleri şubelerden ise veri toplama sürecinde ders programlarında örtüşme meydana gelmeyen şubeler tercih edilmiştir. Belirlenen şubelerde kadın öğretmenin 33 (14 kız, 19 erkek), erkek öğretmenlerin ise 20 ( 8 kız, 12 erkek) ve 31 (8 kız, 23 erkek) öğrencisi bulunmaktadır.

Argümantasyona yönelik yürütülen öğretmen eğitiminde Osborne, Erduran ve Simon (2004b) tarafından gerçekleştirilmiş IDeas, Evidence and Argument in Science (IDEAS) projesi dokümanlarından yararlanılmıştır. Bu dokümanların içeriğinde eğitim paketleri ve sınıf içi örnek uygulama videoları bulunmaktadır.

\section{Sınıf İçi Uygulamaların Yürütülmesi ve Veri Toplama Süreci}

Araştırmanın uygulama faaliyetleri 2016-2017 eğitim öğretim y1lı içerisinde 7. sınıf Elektrik Enerjisi ünitesinde gerçekleştirilmiştir. Uygulama faaliyetleri yaklaşık bir ay sürmüştür ve toplamda 49 ders saatlik veri toplanmıştır. Öğretmenlerden elde edilen ders kayıt miktarları sirasıly 22,15 ve 12 ders saatidir. Saatlerin farklılık göstermesinin temel nedeni veri toplama sürecinde farklı nedenlerden dolayı ders programlarında meydana gelen değişikliklerdir. Veriler toplanırken ses kayıt cihazları ve kameralar kullanılmıştır. Bu cihazlar sınıf içerisine Şekil 2'de ki gibi konumlandırılmıştır.

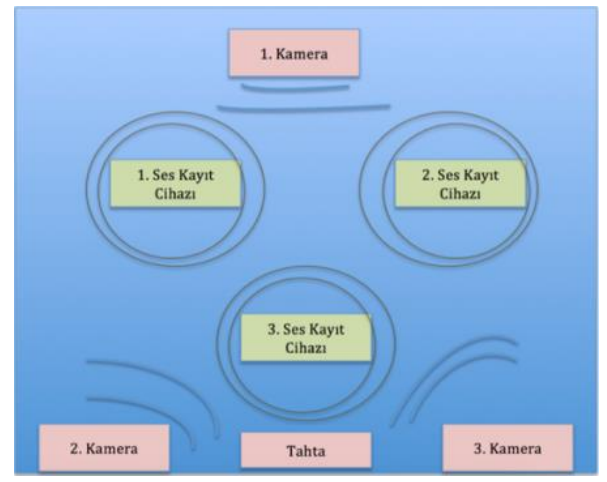

Şekil 2. Veri toplama araçlarının sınıftaki yerleşimi 
Ayrıca öğrenci öğretmen etkileşiminde veri kaybını azaltmak ve daha net sesler elde edebilmek için bir ses kayıt cihazı da öğretmen üzerine yerleştirilmiştir.

\section{Verilerin Transkripti ve Analizi}

Toplanan sınıf içi etkileşim verileri Gail Jefferson (2004) transkript sistematiği esaslarına göre yazılı hale getirilmiştir. Transkript sistematiğinde kullanılan semboller ve kullanım amaçları EK-1'de sunulmuştur. Verilerin analizi sürecinde içeriden bakış açısı (emic perspective) ve gerekçesiz arama (unmotivated search) benimsenerek veriye yaklaşılmıştır. Ayrıca Pomerantz ve Fehr (2011) tarafından ortaya konulan analiz basamakları gerçekleştirilmiştir. Bu basamaklar etkileşimdeki bir dizinin seçilmesi ve açılış kapanış kısımlarının incelenmesi, sözcede meydana gelen olayların nitelendirilmesi, bu olaylar meydana gelirken kullanılan yöntemin tanımlanması, konuşmak için söz sırası alma, sözü kendisinde tutma ve söz sıraları arasındaki geçişlerde ele alınan yöntemin belirlenmesi ve etkileşimde bulunan kişilerin rollerini, kimliklerini sergiledikleri hususların ele alınmasıdır. Ardından bu analiz basamakları ilgili tüm veriye uygulanmıştır. $\mathrm{Bu}$ süreçte öncelikle tek durum analizi ardından benzer özellik gösteren parçalardan meydana gelen koleksiyonlar oluşturularak analiz süreci yürütülmüştür.

\section{Güvenirlik ve Geçerlik}

Araştırma sürecinde ortaya konulan analitik iddiaların geçerliğine yönelik delil oluşturabilmek amacıyla veri analizi sürecinde seçilen kesitler üzerinde önce araştırmacı tarafindan tek durum analizi gerçekleştirilmiştir. Sonraki süreçte Hacettepe Üniversitesi MikroAnaliz, Sosyal Etkileşim ve Öğrenme Araştırma Merkezinde (HUMAN) Konuşma Çözümlemesi alanında çalışan farklı araştırmacıların yer aldığı, veri analizlerinin gerçekleştirildiği veri analizi oturumlarında iki farklı kesit için analiz gerçekleştirilmiştir. Bu durum hem farklı araştırmacılar tarafından üretilen dönütler aracıllğııla araştırmanın geliştirilmesi (Antaki \& Huma, 2018) hem de üretilen analitik iddiaların geçerli olup olmadığını tartışma imkanı sağlamaktadır. Ayrıca analiz gerçekleştirilirken incelenen kesitteki konuşma ve meydana gelen eylemlere bağlı olarak üretilen analitik iddiaların etkileşimde bulunan başka bireyler tarafindan üretilen sözce ve eylemlerle uyuşup uyuşmadığ kontrol edilerek (next-turn-proof) geçerlik ortaya konulmaya çalışılmıştır. 
Güvenirlik Kirk ve Miller tarafından araştırmada üretilen bulguların tesadüfi koşullardan bağımsızlık düzeyi olarak belirtilmektedir (Peräkylä, 2004). Bu hususta Peräkylä (2004) ve Arminen (2005), konuşma çözümlemesi alanında güvenirlik için toplanan verilerin kayıt ve üretilen transkriptlerin kalitesinin oldukça önemli olduğunun üzerinde durmaktadırlar. $\mathrm{Bu}$ doğrultuda veri toplama sürecinde yüksek kalitede kayıt yapan kamera ve ses kayıt cihazları kullanılmış ve elde edilen 49 saatlik (ders saati) veri Gail Jefferson (2004) transkript sistematiğiyle detaylı bir şekilde transkript edilmiştir. Böylece araştırmanın güvenirliği sağlanmaya çalışılmıştır. 


\section{Bulgular}

Yapılan analizler neticesinde argümantasyon sürecinde öğretmen tarafindan kullanıldığı tespit edilen etkileşimsel kaynaklar iki ana başlık altında ele alınmıştır. Bunlar 1) dersin başlatılması sürecindeki etkileşimsel kaynaklar ve 2) argümantasyon sürecindeki etkileşimsel kaynaklardır. Tespit edilen etkileşimsel kaynaklar Tablo 1'de sunulmuştur.

Tablo 1. Tespit edilen etkileşimsel kaynaklar

Dersin başlatılması sürecindeki etkileșimsel kaynaklar

- Sözel dikkat toplama araçları

- Geçiş belirteçleri
- Açıklamaları ve talimatları içeren genişletilmiş öğretmen sözceleri

- Anlamanın kontrolü soruları

Argümantasyon sürecindeki etkileşimsel kaynaklar

- Etkileşimi başlatma araçları (ör. hitap ifadeleri, beden dili işaretleri, göz temas1)

- Öğrenen yanıtını tekrar etme

- Etkileşimi devam ettirmede geçiş belirteci

- Etkileşimi devam ettirme araçları

- Sözel/bedensel dikkat toplama araçları

- Epistemik ve yank1 sorular

- Anladığının iddiasını veya göstergesini sergileme

- Öğretmen dağıtımsız söz sırası almaya izin verme

- Öğrenenden yanıt almak için öğrenme boşluğu verme

- Açılamaları ve talimatları içeren genişletilmiş öğretmen sözceleri

Tablo 1'de sunulan etkileşimsel kaynakların tespit edildiği etkileşim kesitlerine örnek olması amacıyla aşağıda üç kesit sunulmuştur.

\section{Kesit: 1}

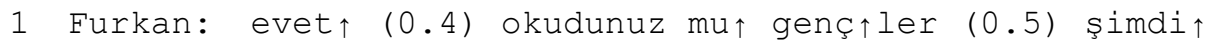

Sözel dikkat toplama arac1 / evet hayır sorusu / geçiş belirteci

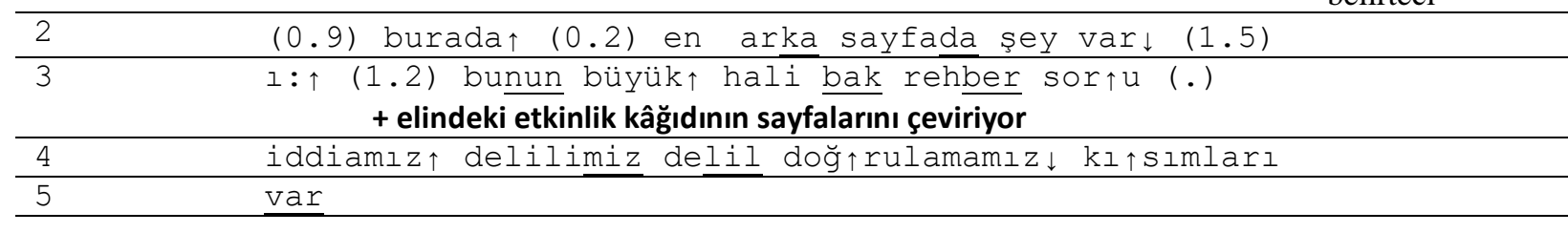


Öğretmen (Furkan) öğrencilerle beraber bir önceki derste belli bir kısmını yürüttükleri etkinliğin kağıtlarını gruplara dağıtmıştır. Ardından öğrencilerin dikkatlerini kendisinde toplamak amacıyla yükselen bir tonlamayla evet (evet $\uparrow$ ) ifadesini üretmiştir (Pekarek Doehler \& PochonBerger, 2015). Kısa bir duraksamanın ardından evet hayır sorusu üretmiştir (Raymond, 2003) (okudunuz mu $\uparrow, 1$. satır) ve yükselen ses tonuyla geçiş belirteci (şimdi $\uparrow$ ) kullanmıştır (Walsh, 2006). Devam eden süreçte öğretmen etkinliğin temel amacı doğrultusunda açıklamalar üretmiştir. $\mathrm{Bu}$ açıklamalar toplamda 18 satır uzunluğundadır. Nitekim bu uzunluk öğretmenin etkinlik sürecine yönelik genişletilmiş yani uzun uzun gerçekleştirilmiş açıklamalar ve talimatlar ürettiğini göstermektedir. Ayrıca süreç içerisinde öğrenci dikkatlerini toplamaya çalıştığı ve derste farklı bir safhaya geçeceğine yönelik belirteç sergilediği görülmektedir.

\section{Kesit: 2}

\begin{tabular}{|c|c|c|c|c|}
\hline 1 & Hülya: & 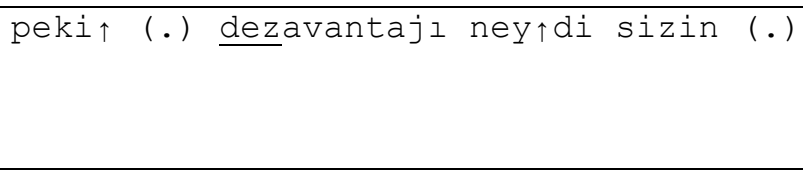 & siz söy $\uparrow$ leyin & $\begin{array}{l}\text { Geçiş belirteci / } \\
\text { epistemik soru } \\
\text { (gönderimsel } \\
\text { soru) }\end{array}$ \\
\hline 2 & Murat: & hocam çok verimli değildir $\downarrow$ & & \\
\hline 3 & & $(0.6)$ & & \\
\hline 4 & Hülya: & 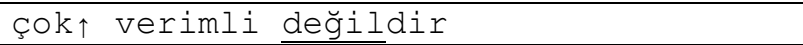 & & \\
\hline 5 & Murat: & her bir güneş pili çok fazla elektrik & üretmez $\downarrow$ & \\
\hline
\end{tabular}

Kesit 2'nin meydana geldiği derste öğrenciler enerji üretim yollarının avantajları ile dezavantajları hakkında tartışmalar yürütmektedirler. Öğretmen (Hülya) gruplardan birinin seçmiş oldukları enerji üretim yöntemi hakkında dezavantaj olarak belirledikleri unsuru ortaya çıartmak için bir geçiş belirteci (peki $\uparrow$ ) (Walsh, 2006) ürettikten sonra epistemik soru sorarak gruba açıklama yapmaları için firsat vermiştir. Ardından grup üyelerinden biri olan Murat söz sırasını alarak yanıt üretmiştir (2. satır). 0.6 saniyelik bir bekleme sonrasında öğretmen üretilen yanıtta belli kelimelere vurgu yaparak (çok $\uparrow$ ve değildir) öğrenen yanıtını tekrar etmiş ve sınıfa duyurmuştur (Walsh, 2012). Kesit açıklamalarından da anlaşılacağı üzere öğretmen etkinlik süreci içerisinde öğrencileriyle etkileşimlerinde geçiş belirteci, epistemik sorular kullanmakta ve öğrenen yanitını tekrar etmektedir.

\section{Kesit: 3}

1 Ayşe : hocam bir ampulle= 
YYÜ Eğitim Fakültesi Dergisi (YYU Journal of Education Faculty), 2021;18(2)494-523, http://efdergi.yyu.edu.tr,

\begin{tabular}{|c|c|c|c|}
\hline 2 & Yakup: & $=\mathrm{hl} h \mathrm{hl}$ & $\begin{array}{l}\text { Etkileşimi devam ettirme } \\
\text { aracı }\end{array}$ \\
\hline 3 & Ayşe : & 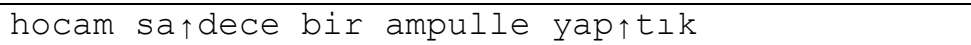 & \\
\hline 4 & Yakup: & 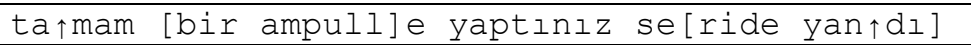 & \\
\hline 5 & Ayşe : & [seride yand] 1 & \\
\hline 6 & Yakup: & [paralelde nasıl yaptınız] & $\begin{array}{ll}\begin{array}{l}\text { Epistemik } \\
\text { (gönderimsel soru) }\end{array} & \text { soru } \\
\end{array}$ \\
\hline 7 & Ayşe : & [ama paralelde iki buçuğa] .hh yanmadı ama iki & \\
\hline
\end{tabular}

Sınıf içi etkileşim anlarının birinde bir öğrenci çalışma grubunda yaptıklarını öğretmene aktarmaya başlamıştır (1. satır). Bu esnada öğretmen (Yakup) etkileşimi devam ettirme aracı kullanarak (=hı hı, 2. satır) (Schegloff, 2007) öğrencinin sözcesini devam ettirmesi için firsat sağlamıştır. Ardından öğrenci sözcesini yeniden belirtmiştir. Süreç içerisinde örtüşen konuşmalar gerçekleşmiştir. Bu örtüşen konuşmaların birinde (6. satır) epistemik soru çeşitlerinden biri olan gönderimsel soru (Long \& Sato, 1983) sormuştur. Dolayısıyla etkileşim süreci içerisinde öğretmenin etkileşimi devam ettirme aracı ve epistemik bir soruyu etkileşim aracı olarak kullandığ1 görülmektedir.

$\mathrm{Bu}$ araştırma kapsamında öğretmenler tarafından argümantasyon tabanlı bilim eğitimi sürecinde kullanılan etkileşimsel kaynaklardan sorular ayrıca incelenmiştir. Bu soruların neler oldukları ve amaçları belirlenmiştir. Elde edilen bulgular Tablo 2'de sunulmuştur.

Tablo 2. Etkileşimsel kaynak olarak kullanılan sorular ve kullanım amaçları

\begin{tabular}{|c|c|c|}
\hline \multirow{9}{*}{$\begin{array}{l}\text { Yank1 } \\
\text { Sorular }\end{array}$} & \multicolumn{2}{|c|}{ Netleştirme İstemi Soruları } \\
\hline & Nasil & Fenomen ile ilgili görüşleri netleştirmek \\
\hline & $\mathrm{Ne}$ & Duymadan kaynaklanan olumsuz durumu oradan kaldırmak \\
\hline & Hangisi & Hangi konu üzerinde konuşulduğunu netleştirmek istemek \\
\hline & Soru edatlar1 & Etkileşimde konuşmada öğrencilerin belirttiği durumu netleştirmeyi istemek \\
\hline & \multicolumn{2}{|c|}{ Anlamanın Kontrolü Soruları } \\
\hline & Soru edatlar1 & Öğrenciye iletilen bilginin anlaşıp anlaşılmadığını kontrol etmek \\
\hline & \multicolumn{2}{|c|}{ Teyit Etme Soruları } \\
\hline & Soru edatlar1 & Öğrenciden edinilen bilginin doğru anlaşılıp anlaşılmadığını teyit ettirmek \\
\hline \multirow{9}{*}{$\begin{array}{l}\text { Epistemik } \\
\text { Sorular }\end{array}$} & \multicolumn{2}{|c|}{ Gösterimsel Sorular } \\
\hline & \multirow{3}{*}{$\mathrm{Ne}$} & Öğrencinin fenomenle ilgili kavramı ortaya koymasını sağlamak \\
\hline & & Öğrencinin etkinliği oluşturan bileşenlerin farkına varmasını sağlamak \\
\hline & & Geçmişte üzerinde durulmuş olan bir konu/durumu gündeme getirmek \\
\hline & \multirow[t]{2}{*}{ Nasil } & $\begin{array}{l}\text { Öğrencilerin fenomen ile ilgili durumların değişkenlere göre nasıl değişti ortaya } \\
\text { koymalarını sağlamak }\end{array}$ \\
\hline & & Öğrencilerin ilgili fenomeni ortaya koymalarını sağlamak \\
\hline & Hangi & Öğrenci deneyimlerini ortaya çıkarmak \\
\hline & Soru edatlar1 & Öğrenci dikkatini belli bir noktaya çekerek düzeltme yapmak \\
\hline & \multicolumn{2}{|c|}{ Gönderimsel Sorular } \\
\hline
\end{tabular}


YYÜ Eğitim Fakültesi Dergisi (YYU Journal of Education Faculty), 2021;18(2)494-523, http://efdergi.yyu.edu.tr,

\begin{tabular}{|c|c|}
\hline \multirow{4}{*}{$\mathrm{Ne}$} & Öğrencilerin gerçekleștirdiği eylemleri ortaya çıkarmak \\
\hline & Öğrencilerin düşüncelerini ortaya çıkarmak \\
\hline & $\begin{array}{l}\text { Fenomenle ilgili gerçekleşmiş bir durum hakkında öğrenci gözlemlerini ortaya } \\
\text { çıarmak }\end{array}$ \\
\hline & Karsı1t görüsler ortaya çıarmak \\
\hline \multirow{2}{*}{ Neden } & Fenomenle ilgili öğrenci düşüncelerini ortaya çıkarmak \\
\hline & Fenomenle ilgili öğrenci iddialarına yönelik gerekçeleri ortaya çıkarmak \\
\hline \multirow[t]{2}{*}{ Nasil } & Öğrenci iddialarına yönelik gerekçeleri ortaya çıkarmak \\
\hline & Fenomenle ilgili öğrenci görüşlerini ortaya çıkarmak \\
\hline Hangisi & $\begin{array}{l}\text { Fenomenle ilgili verilen seçeneklerde (tanılayıcı test maddeleri) öğrenci seçimini, } \\
\text { öğrenci görüşlerini ortaya çıkarmak }\end{array}$ \\
\hline Başka & $\begin{array}{l}\text { Öğrencilerin ilgili durum hakkında alternatif düşünce ve kavramları ortaya } \\
\text { koymasını sağlamak }\end{array}$ \\
\hline
\end{tabular}

Tablo 2'de etkileşimsel kaynak olarak belirtilen soru ifadeleri ve bunların amaçlarının belirlendiği etkileşim kesitlerine örnek olması amacıyla aşağıda yer alan Kesit 4 sunulmuştur. Ayrıca yukarıda incelenen üç kesitte de sorulara yönelik incelemeler sunulmuştur. Kesit 4'te öğrenciler ampul parlaklığını etkileyen etmenlerin ele alındığı bir etkinliği yürütmektedirler. Etkinlik Grooms, Enderle, Hutner, Murphy ve Sampson (2016) tarafindan geliştirilmiştir.

\section{Kesit 4}

\begin{tabular}{|c|c|c|c|c|}
\hline 1 & $\rightarrow$ & Furkan: & siz ne yap tınız(1) [beşinci grup .hhh hah] & $\begin{array}{l}\text { Gönderimsel } \\
\text { soru }\end{array}$ \\
\hline 2 & & Aysun : & [hiç birşey anlayamadı]m hocam & \\
\hline 3 & $\rightarrow$ & Furkan: & 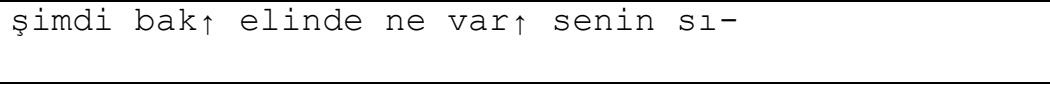 & $\begin{array}{l}\text { Gösterim } \\
\text { sorusu }\end{array}$ \\
\hline 4 & $\rightarrow$ & & sorudan ne anladınız siz & $\begin{array}{l}\text { Gönderimsel } \\
\text { soru }\end{array}$ \\
\hline 5 & & & $(1.4)$ & \\
\hline 6 & & Kübra : & $d \_[:- \text {hocam }]$ & \\
\hline 7 & & Aysun : & [bir pile] & \\
\hline 8 & & Furkan: & hah & \\
\hline 9 & & Kübra : & 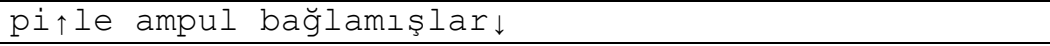 & \\
\hline 10 & $\rightarrow$ & Furkan: & hım bir $\uparrow$ ampulu [mü $\uparrow$ bağlamışlar yok] $\uparrow$ sa & $\begin{array}{l}\text { Gösterim } \\
\text { sorusu }\end{array}$ \\
\hline 11 & & Kübra : & [bunu nasıl etkiler] & \\
\hline 12 & $\rightarrow$ & Furkan: & ampuller mi bağlamışlar & $\begin{array}{l}\text { Gösterim } \\
\text { sorusu }\end{array}$ \\
\hline • & & & $\cdot$ & \\
\hline$\dot{.}$ & & & $\cdot$ & \\
\hline 20 & & Furkan: & =yoo bak bir pile $\uparrow$ bağlı ampüllerin düzenlenmesi & \\
\hline 21 & & & 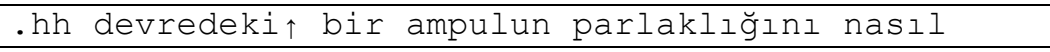 & \\
\hline 22 & & & etkiler (.) bu mu senin söylediğin aynı şey mi & \\
\hline 23 & & & 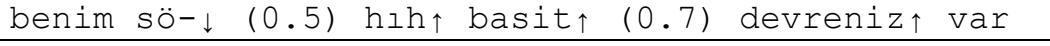 & \\
\hline 24 & & & devrenizdeki ampulleri siz nasıl düzerseniz ampul & \\
\hline 25 & & & parlaklığınız nasıl değişir $\downarrow$ (.) mesele bu & \\
\hline 26 & & Aysun : & $(\quad[\quad)]$ & \\
\hline
\end{tabular}




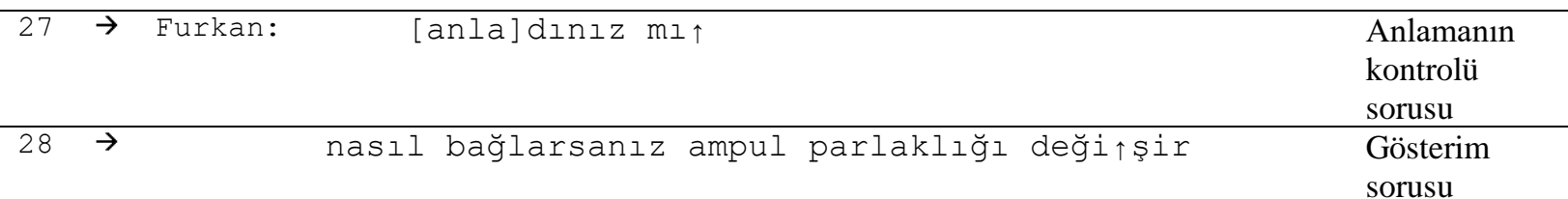

Gösterim sorusu: Öğretmen tarafından yanıtı bilinen soru, Gönderimsel soru: Öğretmen tarafından yanıtı bilinmeyen soru

Öğretmen (Furkan) epistemik soru yapıları içerisinde yer alan gönderimsel bir soru (Long \& Sato, 1983) üreterek öğrencilerden bilgi isteminde bulunmuştur (1. satır). Bu soru öğrencilerin süreç içerisinde gerçekleştirdikleri faaliyetleri ortaya çıkarma niteliğindedir. Süreç içerisinde Aysun isimli öğrencinin anlamadığını ifade etmesi (2. satır) üzerine öğretmen durumu netleştirmek amacıyla hem bir gösterim sorusu (Long \& Sato, 1983) (3. satır) hem de bireylerin görüşlerini açığa çıkarmak amacıyla gönderimsel bir soru üretmiştir (4. satır). Bu sorulara öğrenciler tarafından yanıt gelmesi üzerine öğretmen öğrenci dikkatini belli bir unsura odaklamak amacıyla soru edatından oluşan gösterim sorusu (Long \& Sato, 1983) sormuştur (10. ve 11. satırlar). Bu etkinlikte öğrencilerin birden fazla ampulü çalışır bir şekilde pile bağlaması gerekmektedir. Fakat gelen öğrenci yanıtı (16. satır) üzerinde öğretmen negatif bir değerlendirme gerçekleştirerek etkinliğin içeriği, amacı doğrultusunda uzun bir açıklama yapmıştır. Ardından yapmış olduğu açıklamanın anlaşılıp anlaşılmadığını kontrol edebilmek amacıyla bir anlamanın kontrolü sorusu üretmiş ve devamında gösterim sorusu sorarak öğrenci fikirlerini anlamaya çalışmıştır (Long \& Sato, 1983; Lynch, 1997) (27 ve 28. satırlar).

\section{Tartışma ve Sonuç}

Yapılan analizler neticesinde katılımcı öğretmenlerin argümantasyon tabanlı bir dersin giriş kısmında yaygın bir şekilde dört etkileşimsel kaynak kullandığı tespit edilmiştir. Bunlar sözel dikkat toplama araçları, geçiş belirteçleri, açıklama ve talimatları içeren genişletilmiş öğretmen sözceleri ve anlamanın kontrolü sorularıdır. Son üç kaynak, dil sınıflarında yönetimsel biçimin etkileşimsel unsurları (Sert \& Seedhouse, 2011; Walsh, 2006) olarak ele alınmasına rağmen bahsi geçen etkileşimsel kaynakların genel yapıda olması ve özel şartlara uyarlanabiliyor olması (Dooly, 2009) nedeniyle fen sinfflarında gözlemleniyor olması olağan karşılanabilir.

Dersin hem giriş kısmında hem de ana safhasında öğretmen tarafından üretilen açıklamaları ve talimatları içeren genişletilmiş sözceler pek çok amaçla kullanılmaktadır. Bu çalışmanın bulguları arasında da yer alan, süreç içerisinde yürütülecek etkinliğin tanıtılması, gereklilikler ve beklentilerin ortaya konulmasında bu sözcelerin kullanıldığı bilinmektedir (Ghafarpour, 2017; 
Howard, 2010; Walsh, 2006). Ayrıca argümantasyon sürecinin olmazsa olmazları arasında yer alan karşıt görüşlerin tespit edilmesi ve sınıfa veya grup üyelerine tartışmaya sunulması kısmında da kullanıldığı belirlenmiştir. Bu çalışmanın bulgusuyla aynı zemini paylaşır nitelikte Walsh (2003), öğretmenlerin açıklamalar gerçekleştirme ve teyit etme sürecinde genişletilmiş sözceler ürettiklerini belirtmektedir. Benzer olarak anlamanın kontrolü soruları etkileşimdeki taraflar arasında anlam uzlaşısının gerçekleşip gerçekleşmediğini, sözceleri üreten bireyin karşı taraf tarafından doğru anlaşılıp anlaşılmadığını kontrol etmek amacıyla anlamanın kontrolü sorularının etkileşimsel kaynak olarak kullanıldığı bilinmektedir (Yeon-Hee \& Hyunhee, 2017). Fakat öğretmen tarafından üretilen anlamanın kontrolü soruları, yürütülecek süreç bilgilerinin veya açıklamaya konu olan diğer unsurların bireylerin zihninde doğru bir şekilde yapılandığının kesin delillerini ortaya çıkarmamaktadır. Nitekim bu sorular "anlama" iddiasını ortaya koysa da "anlama"yı göstermemektedir (Waring, 2012a). Bu hususta epistemik soruların kullanılmas1 öğrenmelerin, anlamaların gerçekleşip gerçekleşmediğini açığa çıkarmada daha net deliller sağlayacağ düşünülmektedir.

Sınıf içi etkileşiminin başarılı bir şekilde yürütülmesinde etkileşimde olan bireylerin karş1lıklı olarak düşünceleri anlaması önemli bir husustur. Konuşma ç̧̈zümlemesi alanında bu durumlar anladığının iddiasını sergileme ve anladığının göstergesi kavramlarıyla ifade edilmektedir. Alanyazında bu kavramlara yönelik nasıl gerçekleştirildikleri hususunda pek çok araştırma yer almaktadır (Heritage, 2007; Hindmarsh, Reynolds, \& Dunne, 2011; Koole, 2010). $\mathrm{Bu}$ araştırmalar ağırlıklı olarak öğrenen anlamalarına yönelik olmasına rağmen sınıf içi etkileşimde bir taraf olan öğretmenin, öğrencilerin ifade ve düşüncelerini anlaması ve bunun etkileşimde araç olarak kullanılması oldukça önemlidir. Nitekim bu çalışmada da öğretmenlerin süreç içerisinde anladığının iddiasını veya göstergesini kullandıkları görülmektedir. Bu durumun bir yansıması olarak da öğretmen tarafından öğrenen yanıtının tekrar edilmesi etkileşımsel kaynağı gündeme gelmektedir. Çünkü öğretmen tarafından öğrencinin düşüncesinin anlaşıldığının bir iddiası olarak öğrenen yanıtının tekrar edilmesi (Koole, 2010) söz konusudur. Ayrıca tekrar etme, öğrenenlerin süreç içerisinde kalmalarını sağlamak amacıyla etkileşimsel kaynak olarak da kullanılmaktadır (Walsh, 2012).

Araştırmada öğretmenlerin öğrenenlerden yanıt alma sürecinde öğrenene öğrenme boşluğu verdiği tespit edilmiştir. Nitekim bu süreçte öğrenenlerin anlamalarını paylaşması ve açık, net bir 
yanıt üretebilmesi amacıyla öğrenme boşluğu sunulması oldukça önemli bir husustur (Tobin, 1980; Walsh, 2006). Çünkü sağlanan bu öğrenme boşlukları hem aktif katılım için öğrenciye firsatlar sunar, hem de diyalojik etkileşimi destekler (Walsh \& Li, 2013). Alanyazın incelendiğinde Rowe (1974) fen bilimleri derslerinin işlendiği sınıflarda öğrenenler için öğrenme boşlukları sunulduğunda öğrenciler tarafından üretilen yanıtların uzunluğunda artış gerçekleştiği, bunun yanı sıra hem spekülatif yanıtların hem de delil odaklı çıkarımların oranının arttığı ve üretilen yanıtlardaki başarısızlık durumunun azaldığını ortaya koymaktadır (akt. Tobin, 1980). Fakat ne yazık ki öğrenme boşluğu sunulsa dahi kimi zaman öğrenenlerden istenilen düzeyde yanıt gelmediği (Yataganbaba \& Yildirim, 2016) görülmektedir.

Araştırma bulguları arasında hem dersin başlangıç kısmında hem de ana süreç içerisinde öğretmenlerin geçiş belirteçleri ve dikkat toplama araçlarını etkileşimsel kaynak olarak kullandıkları görülmektedir. Bu araçlardan geçiş belirteçleri dersin olağan akışının değişeceğine yönelik işaret vermede (Swales \& Malczewski, 2001) dikkat toplama araçları ise öğrencinin dikkatini önemli görülen unsura çekerek motivasyonlarını sağlama (Brophy, 2010), aktif katılımlarını sağlama (Pekarek Doehler \& Pochon-Berger, 2015; Schleef, 2008) amaçlarıyla kullanılmaktadır. Nitekim yürütülen araştırmada öğretmenlerin bu araçları kullanması öğrenenleri süreç içerisinde aktif katılımlarını sağlama, motive etme, etkileşimi sürdürme ve sürecin etkili bir şekilde gerçekleştirilmesi için uğraşlarının bir yansıması olarak görülebilir.

Öğretmenler tarafından ders süreci yönetilirken söz sırası vermede beden dilinin kullanılması, göz temasının kurulması ve sözel/bedensel dikkat toplama araçlarının yoğun bir biçimde kullanıldığı tespit edilmiştir. Etkileşimde konuşmada (talk-in-interaction) konuşan bireyin katılımcıya bakışı, ona hitap etmenin belirgin bir biçimidir (Lerner, 2003). Ayrıca söz sırası alma düzeni içerisinde jestlerin kullanılması, olayların gerçekleşmesi ve zamansallığı hususunda önemli kaynaklardır (Mondada, 2007). Çünkü gerçekleşmekte olan eylemin ekolojisi bu kaynakları şekillendirmektedir. Katılımcıların sahip oldukları roller, katılımcıların bakış hususundaki davranışlarını etkilemektedir (Rossano, 2013). Bakışların söz sırası organize etme faaliyetlerinde düzenleyici rolünün araştırıldığı alanyazın incelendiğinde bir konuşmacının konuşmasını bitirmesi ve buna bağlı olarak söz sırasını devretmesi noktasında bakışların etkileşimsel kaynak olarak kullanıldığı ele alınmaktadır (Rossano, 2013). Ayrıca fen bilimleri sınıfları üzerine odaklanılacak olursa konuşma, jest ve diğer beden hareketleri birlikte çalışan grup üyeleri arasındaki odağı 
sürdürmek ve uzlaşıya varma sürecinde öğrencilere yardımcı olmak amacıyla kullanılmaktadır (Tobin, 2006). Ayrıca bu çalışmada öğretmen dağıtımsız söz sırası almaya izin verildiği görülmektedir. $\mathrm{Bu}$ hususa yönelik kurumsal etkileşim açısından yapılandırılmış rollerde bir asimetri durumu bulunmaktadır (Drew \& Heritage, 1992). Bu asimetri içerisinde öğretmen söz sırası alma düzenini organize eden kişidir (Gardner, 2013). Fakat her durumda öğretmen organizasyonu söz konusu değildir (Allwright, 1980). Pedagojik amaçlar ekseninde organizasyon farklılaşabilmektedir (Seedhouse, 2004). Bu durumun bir yansıması olarak da öğrenci başlatımlı etkileşimi meydana gelmektedir. Alanyazın incelendiğinde öğrenci başlatımlı etkileşimlerin ürün olarak daha çeşitli çıktılarla sonuçlanabileceği belirtilmektedir (Damhuis, 2000). Bu durum argümantasyon tabanlı bilim eğitimi bağlamında ele alınacak olursa öğrenenlerin kendi düşüncelerini özgür bir biçimde ifade etme firsatı yakaladıkları ve öğrenen tarafindan başlatılan tartışmalara imkân sağlandığı söylenebilir.

Yürütülen bu araştırmada öğretmenlerin argümantasyon tabanlı bilim eğitimi faaliyetlerinde yaygın olarak epistemik ve yankı sorular ürettikleri görülmektedir. Bu sorular her ne kadar aynı kalıp veya ifade ile ortaya konulmuş olsa da bağlam içerisinde farklı amaçlar doğrultusunda ele alındığı görülmektedir. İlgili alanyazında öğretmenlerin sınıf içi etkileşimde epistemik soru alanında gösterim sorularını gönderimsel sorulara göre daha yaygın olarak kullanıldı̆̆ı ortaya konulmaktadır (Farahian \& Rezaee, 2012; McNeil, 2012). Ne yazık ki gösterim sorularının hem hedef dilin kullanımı (Brock, 1986) hem de detaylı öğrenci konuşmaları hususunda (Cazden, 2001) etkili olmadığı ifade edilmektedir. Çünkü gösterim sorularının, esasları itibariyle olguları hatırlama ve farkına varmaya yönelik, başka bir açıdan düşük düzeyde bilişsel uğraşa yönelik olduğu belirtilmektedir (Brock, 1986). Fakat bu hususa yönelik olarak gönderimsel sorular, öğrenmeyi desteklemekte ve hedef dilin kullanımına firsatlar sağlamaktadır (Brock, 1986; McNeil, 2012). Ayrıca gönderimsel soruların hem öğrencilerin daha uzun yanıtlar vermesini ve üst düzey düşünmelerini sağladığı, hatırlama düzeyi bilişsel faaliyetinden ziyade kavramsal anlamalarını belirtme imkanı sunduğu (Oliveira, 2010) ve etkileşimde olan katılımcılar için anlamlı müzakereye ortam sunduğu (Behnam \& Pouriran, 2009) düşünülmektedir. Gösterimsel ve gönderimsel sorular arasındaki yukarıda belirtilen durum, benzer olarak daha büyük ölçekte yankı soru ve epistemik soru uygulamaları arasında da söz konusudur. Epistemik sorular yankı sorulara 
göre öğrencinin kendini ifade etmesi, anlamalarını sergilemesi için daha fazla imkan sağlamaktadır (Oliveira, 2010).

Yankı soru türleri içerisinde ise netleştirme istemlerine yönelik sorular öğrenci öğrenmelerini desteklemede önemli etkileşim aracı olarak kullanılmaktadır (Walsh, 2006). Bu tür sorular yanıt üreten bireyi ürettiği yanıtı yeniden ifade etme, farklı kelimelerle açıklama, başka bir ifadeyle yanıtı yeniden organize etmeye sevk etmektedir (Suryati, 2015; Walsh, 2006). Dolayısıyla yanıt üreten bireyin zihninde bilgiyi nasıl yapılandırdığını ortaya çıkartmak için fırsatlar sağlamaktadır. Fakat teyit etme ve anlamanın kontrolü sorularında bu durum geçerli değildir.

Bu çalışmanın sonuçları argümantasyon tabanlı bilim eğitiminin gerçekleştiği fen bilimleri sınıflarında öğretmenler tarafından kullanılan etkileşimsel kaynakları ve bu kaynaklar içirişinde yer alan sorular ve bu soruların amaçlarını ortaya koymaktadır. Bu bağlamda sınıf içi etkileşim dinamikleri, kaynakları ortaya çıkarılmıştır. Sınıf içinde diyalojik kültürün oluşturulması ve sürdürülmesinde bu kaynaklar önemli araçlar olarak işlev görmektedir. Dolayısıyla hem öğretmen eğiticileri hem de öğretmenler tarafından bu kaynakların farkında olunması ve sınıf içi etkileşimin organize edilmesinde bilinçli olarak kullanılması gerekmektedir. Bu bağlamda analitik veri sunan, farklı kurumsal ortamlarda bu tür araştırmaların yürütülmesi alana katkı sağlayacaktır. Ayrıca bu çalışmada konuşma çözümlemesi yaklaşımı kullanılmıştır. Bu yaklaşımla sınıf içi etkileşime yönelik oldukça detaylı veri sunularak analitik iddialar üretilmektedir. Dolayısıyla fen eğitimi araştırmacıları tarafından bu yaklaşımın benimsenerek araştırmalar gerçekleştirilmesi, sınıf verilerinin ele alınmasına yeni bakış açıları kazandıracaktır. Araştırmacıların bu yaklaşımı kullanarak araştırmalar yürütmeleri önerilmektedir.

\section{Makalenin Bilimdeki Konumu}

Matematik ve Fen Bilimleri Eğitimi Bölümü/Fen Bilgisi Eğitimi

\section{Makalenin Bilimdeki Özgünlüğü}

Argümantasyon, bilimin önemli bir bileşeni olup fen eğitiminde özellikle üzerinde durulan bir konudur. Araştırmacılar öğrencilerin ürettikleri argümanların niteliğini artırmak için çalışmalar yürütmektedir. Bu çalışmalar ağırlıklı olarak yazılı argüman üzerine odaklanmaktadır. Fakat bu çalışmada diyalojik argümantasyon sürecinde öğretmenlerin öğrenmenin niteliğini artırmaya yönelik sınıf içi etkileşim anında kullandıkları etkileşimsel kaynaklar, bu etkileşimsel kaynaklar arasında yer alan sorular ve bu soruların kullanım amaçları araştırılmıştır. Bu sebepten dolayı alan 


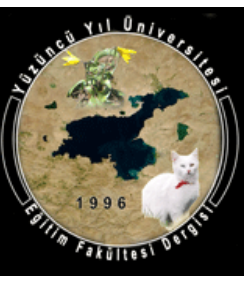

YYÜ Eğitim Fakültesi Dergisi (YYU Journal of Education Faculty), 2021;18(2)494-523, http:/lefdergi.yyu.edu.tr,

yazına özellikle diyalojik argümantasyon alanına katkı sağlamaktadır. Ayrıca yöntem kısmında kullanılan Konuşma Çözümlemesi yönteminin fen eğitimi araştırmacılarına yeni bakış açıları sunacağı düşünülmektedir. 


\section{Kaynakça}

Allwright, R. L. (1980). Turns, topics, and tasks: Patterns of participation in language learning and teaching. In D. Larsen-Freeman (Ed.), Discourse analysis in second language research (pp. 165-187). Rowley, MA: Newbury House Publishers, Inc.

Alozie, N. M., Moje, E. B., \& Krajcik, J. S. (2010). An analysis of the supports and constraints for scientific discussion in high school project-based science. Science Education, 94(3), 395427. doi:10.1002/sce.20365

Antaki, C., \& Huma, B. (2018, 30.05.2018). Research on language and social interaction: Data sessions world-wide. Retrieved from https://rolsi.net/teaching-2/data-sessions/

Arminen, I. (2005). Institutional interaction: Studies of talk at work. England: Ashgate Publishing Limited.

Aydeniz, M., \& Gurcay, D. (2013). Assessing quality of pre-service physics teachers' written arguments. Research in Science \& Technological Education, 31(3), 269-287.

Behnam, B., \& Pouriran, Y. (2009). Classroom discourse: Analyzing teacher/learner interactions in Iranian EFL task-based classrooms. Porta Linguarum(12), 117-132.

Bennett, A. (1982). Strategies and counterstrategies in the use of yes-no questions in discourse. In J. J. Gumperz (Ed.), Language and social identity (pp. 95-107). United States of America: Cambridge University Press.

Berland, L. K., \& McNeill, K. L. (2010). A learning progression for scientific argumentation: Understanding student work and designing supportive instructional contexts. Science Education, 94(5), 765-793.

Brock, C. A. (1986). The effects of referential questions on ESL classroom discourse. TESOL Quarterly, 20(1), 47-59. doi:10.2307/3586388

Brophy, J. (2010). Motivating students to learn ( $3^{\text {rd }}$ ed.). New York: Routledge.

Cazden, C. B. (2001). Classroom discourse: The language of teaching and learning (2nd ed.). Portsmouth, NH: Heinemann.

Chin, C. (2007). Teacher questioning in science classrooms: Approaches that stimulate productive thinking. Journal of Research in Science Teaching, 44(6), 815-843. doi:10.1002/tea.20171

Chin, C., \& Osborne, J. (2010). Students' questions and discursive interaction: Their impact on argumentation during collaborative group discussions in science. Journal of Research in Science Teaching, 47(7), 883-908. doi:10.1002/tea.20385 
Clark, D., Sampson, V., Weinberger, A., \& Erkens, G. (2007). Analytic frameworks for assessing dialogic argumentation in online learning environments. Educational Psychology Review, 19(3), 343-374. doi:10.1007/s10648-007-9050-7

Cunningham, R. T. (1987). What kind of question is that? In W. W. Wilen (Ed.), Questions, questioning techniques, and effective teaching (pp. 67-94). Washington D.C.: National Education Association.

Damhuis, R. (2000). A different teacher role in language arts education: Interaction in a small circle with teacher. In J. K. Hall \& L. S. Verplaetse (Eds.), Second and foreign language learning through classroom interaction (pp. 243-264). London: Lawrence Erlbaum Associates.

Dooly, M. (2009). Doing diversity: Teachers' construction of their classroom reality (Vol. 82). Germany: Peter Lang.

Drew, P., \& Heritage, J. (1992). Analyzing talk at work: An introduction. In P. Drew \& J. Heritage (Eds.), Talk at work: Interaction in institutional settings (pp. 3-65). Cambridge: Cambridge University Press.

Duschl, R. (2007). Quality argumentation and epistemic criteria. In S. Erduran \& M. P. JiménezAleixandre (Eds.), Argumentation in science education: Perspectives from classroombased research (pp. 159-175). Dordrecht: Springer.

Erdogan, I., \& Campbell, T. (2008). Teacher questioning and interaction patterns in classrooms facilitated with differing levels of constructivist teaching practices. International Journal of Science Education, 30(14), 1891-1914. doi:10.1080/09500690701587028

Erduran, S. (2019). Argumentation in chemistry education: An overview Argumentation in chemistry education: Research, policy and practice (pp. 1-10): The Royal Society of Chemistry.

Erduran, S., \& Jiménez-Aleixandre, M. P. (Eds.). (2007). Argumentation in science education: Perspectives from classroom-based research.

Erduran, S., Simon, S., \& Osborne, J. (2004). TAPping into argumentation: Developments in the application of Toulmin's Argument Pattern for studying science discourse. Science Education, 88(6), 915-933. doi:10.1002/sce.20012 
Eshach, H., Dor-Ziderman, Y., \& Yefroimsky, Y. (2014). Question asking in the science classroom: Teacher attitudes and practices. Journal of Science Education and Technology, 23(1), 67-81. doi:10.1007/s10956-013-9451-y

Farahian, M., \& Rezaee, M. (2012). A case study of an EFL teacher's type of questions: An investigation into classroom interaction. Procedia - Social and Behavioral Sciences, 47, 161-167. doi:10.1016/j.sbspro.2012.06.631

Furtak, E. M., Bakeman, R., \& Buell, J. Y. (2018). Developing knowledge-in-action with a learning progression: Sequential analysis of teachers' questions and responses to student ideas. Teaching and Teacher Education. 76, 267-282. doi: 10.1016/j.tate.2018.06.001

Gardner, R. (2013). Conversation analysis in the classroom. In J. Sidnell \& T. Stivers (Eds.), The handbook of conversation analysis (pp. 593-611). West Sussex: Wiley-Blackwell.

Ghafarpour, H. (2017). Classroom conversation analysis and critical reflective practice: Selfevaluation of teacher talk framework in focus. RELC Journal, 48(2), 210-225. doi:10.1177/0033688216631173

Grooms, J., Enderle, P. J., Hutner, T., Murphy, A., \& Sampson, V. (2016). Argument-driven inquiry in physical science: Lab investigations for grades 6-8. Arlington, Virginia: National Science Teachers Association Press.

Halvorsen, K. (2018). Questions as interactional resource in team decision making. International Journal of Business Communication, 55(1), 69-93. doi:10.1177/2329488415589102

Heritage, J. (2007). Intersubjectivity and progressivity in references to persons (and places) reference. In N. J. Enfield \& T. Stivers (Eds.), Person reference in interaction: Linguistic, cultural and social perspectives (pp. 255-280). New York: Cambridge University Press.

Hindmarsh, J., Reynolds, P., \& Dunne, S. (2011). Exhibiting understanding: The body in apprenticeship. Journal of Pragmatics, 43(2), 489-503. doi:10.1016/j.pragma.2009.09.008

Howard, A. (2010). Is there such a thing as a typical language lesson? Classroom Discourse, 1(1), 82-100. doi:10.1080/19463011003750699

Jefferson, G. (1974). Error correction as an interactional resource. Language in Society, 3(2), 181199. doi:10.1017/S0047404500004334

Jefferson, G. (2004). Glossary of transcript symbols with an introduction. In G. H. Lerner (Ed.), Conversation analysis: Studies from the first generation (Vol. 125, pp. 13-34). Philadelphia: John Benjamins Publishing Company. 
Kääntä, L., \& Kasper, G. (2018). Clarification requests as a method of pursuing understanding in CLIL physics lectures. Classroom Discourse, 9(3), 205-226. doi:10.1080/19463014.2018.1477608

Kawalkar, A., \& Vijapurkar, J. (2013). Scaffolding science talk: The role of teachers' questions in the inquiry classroom. International Journal of Science Education, 35(12), 2004-2027. doi:10.1080/09500693.2011.604684

Kim, M., \& Roth, W. M. (2018). Dialogical argumentation in elementary science classrooms. Cultural Studies of Science Education, 13(4), 1061-1085. doi:10.1007/s11422-017-98469

Koole, T. (2010). Displays of epistemic access: Student responses to teacher explanations. Research on Language and Social Interaction, 43(2), 183-209. doi:10.1080/08351811003737846

Koshik, I. (2002). A conversation analytic study of yes/no questions which convey reversed polarity assertions. Journal of Pragmatics, 34(12), 1851-1877. doi:10.1016/S03782166(02)00057-7

Lehesvuori, S., Hähkiöniemi, M., Jokiranta, K., Nieminen, P., Hiltunen, J., \& Viiri, J. (2017). Enhancing dialogic argumentation in mathematics and science. Studia Paedagogica, 22(4), 55-76. doi:10.5817/SP2017-4-4

Leitão, S. (2000). The potential of argument in knowledge building. Human Development, 43(6), 332-360. doi:10.1159/000022695

Lerner, G. H. (2003). Selecting next speaker: The context-sensitive operation of a context-free organization. Language in Society, 32(2), 177-201. doi:10.1017/S004740450332202X

Long, M. H., \& Sato, C. J. (1983). Classroom foreigner talk discourse: Forms and functions of teachers' questions. In H. W. Seliger \& M. H. Long (Eds.), Classroom oriented research in second language acquisition (pp. 268-285). Rowley, MA: Newbury House.

Lynch, T. (1997). Nudge, nudge: Teacher interventions in task-based learner talk. ELT journal, 51(4), 317-325.

McNeil, L. (2012). Using talk to scaffold referential questions for English language learners. Teaching and Teacher Education, 28(3), 396-404. doi:10.1016/j.tate.2011.11.005 
McNeill, K. L., \& Knight, A. M. (2013). Teachers' pedagogical content knowledge of scientific argumentation: The impact of professional development on K-12 teachers. Science Education, 97(6), 936-972. doi:10.1002/sce.21081

MEB. (2018). Fen bilimleri dersi ögretim programı (ilkokul ve ortaokul 3, 4, 5, 6, 7 ve 8. sinıflar). Ankara: Milli Eğitim Bakanlı̆̆ı.

Mehan, H. (1979). Learning lessons: Social organization in the classroom. Cambridge, MA: Harvard University Press.

Mondada, L. (2007). Multimodal resources for turn-taking: Pointing and the emergence of possible next speakers. Discourse Studies, 9(2), 194-225.

NRC. (2012). A frameworkfor K-12 science education: Practices, crosscuting concepts, and core ideas. Washington, DC: National Academies Press.

Nussbaum, E. M. (2011). Argumentation, dialogue theory, and probability modeling: Alternative frameworks for argumentation research in education. Educational Psychologist, 46(2), 84106. doi:10.1080/00461520.2011.558816

Oliveira, A. W. (2010). Improving teacher questioning in science inquiry discussions through professional development. Journal of Research in Science Teaching, 47(4), 422-453. doi:10.1002/tea.20345

Osborne, J., Erduran, S., \& Simon, S. (2004a). Enhancing the quality of argumentation in school science. Journal of Research in Science Teaching, 41(10), 994-1020. doi:10.1002/tea.20035

Osborne, J., Erduran, S., \& Simon, S. (2004b). IDeas, Evidence \& Argument in Science CPD Training Pack. London: King’s College London.

Pekarek Doehler, S., \& Pochon-Berger, E. (2015). The development of L2 interactional competence: Evidence from turn-taking organization, sequence organization, repair organization and preference organization. In T. Cadierno \& S. W. Eskildsen (Eds.), Usagebased perspectives on second language learning (Vol. 30, pp. 233-268). Germany: De Gruyter Mouton.

Peräkylä, A. (2004). Reliability and validity in research based on naturally occurring social interaction. In D. Silverman (Ed.), Qualitative research: Theory, method and practice (pp. 283-304). London: SAGE Publications. 
Pomerantz, A., \& Fehr, B. (2011). Conversation analysis: An approach to the analysis of social interaction. In T. A. V. Dijk (Ed.), Discourse studies: A multidisciplinary introduction (pp. 165-190). London: SAGE Publications Ltd.

Raymond, G. (2003). Grammar and social organization: Yes/no interrogatives and the structure of responding. American Sociological Review, 68(6), 939-967. doi:10.2307/1519752

Rossano, F. (2013). Gaze in conversation. In J. Sidnell \& T. Stivers (Eds.), The handbook of conversation analysis (pp. 308-329). West Sussex: Wiley-Blackwell.

Sampson, V., Grooms, J., \& Walker, J. P. (2011). Argument-driven inquiry as a way to help students learn how to participate in scientific argumentation and craft written arguments: An exploratory study. Science Education, 95(2), 217-257. doi:10.1002/sce.20421

Schegloff, E. A. (2007). Sequence organization in interaction: A primer in conversation analysis (Vol. 1). New York: Cambridge University Press.

Schleef, E. (2008). The "lecturer's OK" revisited: Changing discourse conventions and the influence of academic division. American Speech, 83(1), 62-84. doi:10.1215/000312832008-003

Seedhouse, P. (2004). The interactional architecture of the language classroom: A conversation analysis perspective. Malden, MA: Blackwell.

Sert, O., Balaman, U., Can Daşkın, N., Büyükgüzel, S., \& Ergül, H. (2015). Konuşma çözümlemesi yöntemi. Mersin Üniversitesi Dil ve Edebiyat Dergisi, MEUDED, 12(2), 143.

Sert, O., \& Seedhouse, P. (2011). Introduction: Conversation analysis in applied linguistics. Novitas-ROYAL (Research on Youth and Language), 5(1), 1-14.

Sidnell, J. (2009). Comparative perspectives in conversation analysis. In J. Sidnell (Ed.), Conversation analysis: Comparative perspectives (pp. 3-27). New York: Cambridge University Press.

Sidnell, J. (2010). Conversation analysis: An introduction. Malden: Wiley-Blackwell.

Silverman, D. (2014). Interpreting qualitative data

Suryati, N. (2015). Classroom interaction strategies employed by english teachers at lower $\begin{array}{lllll}\text { secondary } \quad \text { schools. } & \text { TEFLIN }\end{array}$ doi:10.15639/teflinjournal.v26i2/247-264 
Swales, J. M., \& Malczewski, B. (2001). Discourse management and new-episode flags in MICASE. In R. C. Simpson \& J. M. Swales (Eds.), Corpus linguistics in North America: Selections from the 1999 symposium (pp. 145-164). Ann Arbor, MI: University of Michigan Press.

Tobin, K. G. (1980). The effect of an extended teacher wait-time on science achievement. Journal of Research in Science Teaching, 17(5), 469-475. doi:10.1002/tea.3660170514

Tobin, K. G. (2006). Aligning the cultures of teaching and learning science in urban high schools. Cultural Studies of Science Education, 1(2), 219-252. doi:10.1007/s11422-005-9008-3

van Zee, E., Iwasyk, M., Kurose, A., Simpson, D., \& Wild, J. (2001). Student and teacher questioning during conversations about science. Journal of Research in Science Teaching, 38(2), 159-190. doi:10.1002/1098-2736(200102)38:2<159::AID-TEA1002>3.0.CO;2-J

Walsh, S. (2003). Developing interactional awareness in the second language classroom through teacher self-evaluation. Language Awareness, 12(2), 124-142. doi:10.1080/09658410308667071

Walsh, S. (2006). Investigating classroom discourse. New York: Routledge.

Walsh, S. (2012). Conceptualising classroom interactional competence. Novitas-ROYAL (Research on Youth and Language), 6(1), 1-14.

Walsh, S., \& Li, L. (2013). Conversations as space for learning. International Journal of Applied Linguistics, 23(2), 247-266. doi:10.1111/ijal.12005

Waring, H. Z. (2012a). “Any questions?”: Investigating the nature of understanding-checks in the language classroom. TESOL quarterly, 46(4), 722-752. doi:10.1002/tesq.48

Waring, H. Z. (2012b). Yes-no questions that convey a critical stance in the language classroom. Language and Education, 26(5), 451-469. doi:10.1080/09500782.2012.656651

Yataganbaba, E., \& Yildirim, R. (2016). Teacher interruptions and limited wait time in EFL young learner classrooms. Procedia - Social and Behavioral Sciences, 232, 689-695. doi:10.1016/j.sbspro.2016.10.094

Yeon-Hee, J., \& Hyunhee, C. (2017). Comparison of questions used by teachers with expertise and little expertise in elementary english classes. The SNU Journal of Education Research, 26(4), 89-107. 


\section{Extended Summary of the Study}

\section{Introduction}

Argumentation is an advocated scaffolding for science education (Erduran, 2019. However, students and teachers face various difficulties due to the non-linear nature of the process in the dialogic argumentation process (Kim \& Roth, 2018). In addition, teachers have problems in creating and facilitating the dialogic culture (Alozie, Moje, \& Krajcik, 2010) and in producing and using appropriate questions to support student learning, even if they use a curriculum that provides opportunities for them to carry out argumentation activities in the classroom (McNeill \& Knight, 2013). For these reasons, this study investigates the interactional resources used by science teachers, the questions used as interactional resources, and the purposes of these questions in argumentation-based science education by focusing on classroom interaction. Within this scope, the research questions directing the study are:

- What are the interactional resources used by science teachers in argumentation-based science education?

- What are the questions that the teachers use as interactional resources and the purposes of using these questions in argumentation-based science education?

\section{Method}

This study was set as a qualitative nature in perspective of Conversation Analysis. The study has three main stages. In the first stage is the determination of volunteer teachers and the execution of teacher training. The second stage is the implementation of classroom practices with the volunteer teachers. The last stage is the examination of data obtained in the process.

One female and two male teachers enrolled in the study. Female teachers have 33 (14 girls, 19 boys), and a male teacher has 20 (8 girls, 12 boys) and another male teacher 31 ( 8 girls, 23 boys) students. The teachers performed classroom implementations with their 7 th-grade students in the Electrical Energy unit in the 2016-2017 academic year. Forty-nine lesson hours of data were collected. 
The collected classroom interaction data were transcribed regarding to the principles of Gail Jefferson (2004) transcript systematics. In the data analysis, data were approached by the emic perspective and unmotivated search. In addition, the analysis steps introduced by Pomerantz and Fehr (2011) were carried out.

\section{Results}

We determined some interactional resources that the teachers used in their lessons to support dialogical argumentation. We presented them into two sub-stages, which are the early and main stages of lessons. The teachers used (a) verbal getting attention tools, (b) extended turns containing explanations and instructions, (c) transitional makers, and (d) comprehension check questions as an interactional resource in the early stages of the lessons. They also used (a) epistemic and echoic questions, (b) displaying the claiming and demonstrating of understanding, (c) allowing to take turns without teacher distribution, (d) extended waiting time to get answers from the student, (e) extended turns containing explanations and instructions, (f) tools to initiate and maintain interaction (g) transitional makers to maintain interaction (h) verbal/physical getting attention tools, and (i) repeating learner response as interactional resources in the main stages of the lessons.

We also revealed questions that teachers used as interactional resources and their purposes. The teachers used clarification request questions, comprehension check questions, and confirmation check questions as echoic questions. They also used display questions and referential questions as epistemic questions. Teachers ask these questions for different purposes depending on the context. For example, clarifying the student's view about the phenomenon, revealing student views and counter views, and revealing the warrants for students' claims about the phenomenon are among their common uses.

\section{Conclusion and Discussion}

In this study, we determined interactional resources and revealed questions and their purposes. The results indicate that the teachers use interactional resources to support dialogical argumentation and to perform argumentation-based science activities successfully. These 
resources provide opportunities for the learning process by keeping students in interaction and disclosing their thoughts, claims, warrants, or counter views about the phenomenon. Results of many research in which researchers examined interactional features point out similar results (e.g., Walsh, 2006). The results also display that the teachers ask display, referential, clarification request, confirmation check, and comprehension check questions. In the literature, it is revealed that teachers prefer using echoic questions more than epistemic questions. However, epistemic questions provide more opportunities for students to express themselves and demonstrate their understanding (Oliveira, 2010). Clarification request questions are an essential interaction tool to support student learning among the echoic questions (Walsh, 2006). Such questions lead the respondent to re-express the answer, to explain it with different words (Suryati, 2015; Walsh, 2006). Lastly, teachers use display questions more commonly than referential questions in the field of epistemic questions in classroom interaction (Farahian \& Rezaee, 2012; McNeil, 2012). Unfortunately, it is known that display questions are not effective on both the use of the target language (Brock, 1986) and detailed student conversations (Cazden, 2001).

EK-1: Gail Jefferson transkript sembolleri ve kullanım amaçları (Jefferson, 2004)

\begin{tabular}{ll}
\hline Sembol & Kullanım amacı \\
\hline$[$ ] & Aynı anda gerçekleşen konuşmanın başlama ve bitiş anlarını göstermek \\
$()$. & Anlık bir duraksamayı göstermek \\
$(0.0)$ & Geçen süreyi saniye olarak sunmak \\
$=$ & Sözceler arası süre, boşluk olmadığını belirtmek \\
$::$ & Sesin uzatılarak söylendiğini belirtmek \\
- & Konuşmanın kesildiğini göstermek \\
$\uparrow$ veya $\downarrow$ & Anlı yükselen tonlama veya düşen tonlamayı belirtmek \\
okelime & Çevredeki seslerden daha az, kısık, düşük sesle söylendiğini belirtmek \\
.hhh & Nefes almayı belirtmek \\
metin & İfadedeki vurguyu belirtmek \\
\hline Not: Gail Jefferson transkript sembolleri ve kullanım amaçlarına yönelik Türkçe, daha detaylı ve kapsamlı bilgiye \\
erişmek için Sert vd. (2015) tarafından üretilen yayına bakılabilir.
\end{tabular}

